\title{
AT THE TABLE WITH THE BIG THREE CARNIVORES IN SLOVAKIA - A SYMPATRIC OCCURRENCE OF THE GOLDEN JACKAL IN THE HABITAT OF THE THREE NATIVE LARGE CARNIVORES CAPTURED ON A CAMERA TRAP
}

\author{
GuimarÃes N.F. ${ }^{1,2,3 *}$, Slamka M. ${ }^{4}$, BuČKo J. ${ }^{5}$ \\ ${ }^{1}$ Department of ecology, Faculty of humanities and natural sciences, University of Prešov, \\ Prešov, Slovakia; \\ ${ }^{2}$ Diana OZ - Carpathian Wildlife Research, Mladeznicka 47, 97404 Banská Bystrica, Slovakia; \\ ${ }^{3}$ The Centre of Natural Sciences, Research and Environmental Education - Little Fox - Staré \\ Hory 344, 97602 Staré Hory, Slovakia; \\ ${ }^{4}$ Forest Research Institute in Zvolen, National Forest Centre SR, 96001 Zvolen, Slovakia; \\ ${ }^{5}$ Institute for Forest Resources and Information, National Forest Centre SR, 96001 \\ Zvolen, Slovakia \\ *Corresponding author: nunoguimaraes08@gmail.com
}

\begin{abstract}
.
In the last decades, golden jackals expanded significantly their distribution range in Europe, as well as considerably increased their population density and today their presence is official in many countries. Since the first reported occurrences in 1989, dispersion and population in Slovakia follow the European trend and from 2009 numbers are increasing at a constant rate. In Slovakia, camera traps records of the three native large carnivore species, in places where they share the same habitat are rather common, while the ones with golden jackals are still rare, despite a large number of active camera traps around the country. In this work, we report an anecdotal sympatric occurrence of the golden jackal with wolf, lynx and bear from one camera trap installed in the east side of the Kysuce Protected Landscape Area. Located in mountainous habitat with a high forest cover, this occurrence also shows the flexibility of the golden jackal concerning different habitat use along their range or within dispersion routes, inclusive in areas where large carnivores are present.
\end{abstract}

Key words: Canis aureus, Canis lupus, coexistence, Lynx lynx, Ursus arctos

\section{INTRODUCTION}

The golden jackal (Canis aureus L. 1758) (hereafter jackal) is a true generalist species and it is one of the most widespread canids in the world (Jhala \& Moehlman 2004, 2008, Arnold et al. 2012, Trouwborst et al. 2015, Krofel et al. 2017). The behavioural characteristics of this mesopredator, together with its highly opportunistic feeding habits, allowed the species to expand their range in Europe and establish territories in a wide variety of habitats and climatic conditions (Giannatos 2004, Šálek et al. 2014, Ranc et al. 2018, Spassov \& Acosta-Pankov 2019). Jackals are social animals, found to live in monogamous pairs or in organized family groups, but can easily live as solitaire vagrants with a great capacity for dispersion inclusive within long distances (Macdonald 1979, Lanszki et al. 2018). Jackals are generally most active at crepuscular hours but when living near human settlements their pattern activity is more nocturnal (Ginsberg and Macdonald 1990, Ambarli et al. 2016). However, when the level of human persecution is low, jackals can also be very active during daylight (Sillero-Zubiri et al. 2004).

Jackals feeding habits includes a variety of different resources, from many wild smaller sized animals (e.g. mammals, birds) and plants (e.g. fruits, grasses), to carrion (e.g. scavenging prey killed by other carnivores) and anthropogenic food (e.g. waste/ garbage, viscera from hunters leftovers) (Giannatos et al. 2010, Penezić \& Ćirović 2015, Lanszki et al. 2016).

The first evidence of the presence of the jackal in many European countries goes back to the ' 80 s, when their most recent dispersion started, from the core area in the Balkans region (Demeter \& Spassov 1993, Kryštufek et al.1997, Giannatos et al. 2005, 
Lanszki \& Heltai 2010, Arnold et al. 2012, Trouwborst et al. 2015, Krofel et al. 2017). Nowadays, their distribution range all over Europe together with the population numbers are still increasing as well as records concerning reproduction (Rutkowski et al. 2015, Hatlauf et al. 2016 and 2017, Slamka et al. 2017, Jirků et al. 2018, Ranc et al. 2018, Guimaraes et al. 2017 and 2019, Kowalczyk et al. 2020). The wide variability of occupied habitats has direct connection with the availability of food and the presence of areas suitable for shelter and denning (Giannatos 2004, Jhala \& Moehlmann 2004). Although it is much common to find jackals in areas with altitudes up to 600 m.a.s.l., there are records of their presence at 1800 m.a.s.l but this may be considered extreme situation (Spassov \& Acosta-Pankov 2019). Nevertheless, they were also recorded colonizing habitats within the altitude average of 900 m.a.s.l., with a maximum of 1080 m.a.s.l., and in this particular study case records where located in an area occupied previously by wolves (Giannattos et al. 2005).

The coexistence between large carnivores and mesocarnivores can be enabled by each species ecological needs, trophic preferences, a difference of habitat use, activity patterns, and the way they use home range space (Ritchie \& Johnson 2009, Newsome et al. 2017, Haswell et al. 2018). Therefore coexistence between jackals and the three most common large carnivores present in Europe, the grey wolf (Canis lupus; hereafter wolf), Eurasian lynx (Lynx lynx; hereafter lynx), and the brown bear (Ursus arctos; hereafter bear), can be expected to be influenced by the distribution and abundance of each of top predators (Newsome et al. 2017, Haswell et al. 2018). Studies about sympatric occurrences of jackals with wolves showed that these two species are not compatible to coexist in the same areas and normally where there are stable wolf packs the jackal is absent or rare (Giannatos et al. 2005; Krofel et al. 2017). A specific study developed in 2017 by Krofel et al., describing the historic development of territory distributions of jackals and wolves, focusing mostly on the mesopredator release, show that wolves influence presence/absence of jackals', in their distribution/ dispersion and settlement in new areas (Krofel et al. 2017). Although studies related to sympatric occurrences of jackals with the lynx are still not common, it is expectable that they will relate to the relationship between lynx and foxes, in which lynx have a direct negative effect on this mesopredator, by supressing its abundance (Pasanen-Mortensen et al. 2013, Am- barli et al. 2016). In relation to the coexistence of jackals and bears, although studies are not available and the diet of both species overlap, it might be the less problematic from all three large carnivore relationships and less expected to take a form of intraguild predation (Holt \& Polis 1997, Štofik et al. 2014, Lanszki et al. 2016).

Within the last 10 years, it is clear that the distribution and abundance of the jackal are increasing in Slovakia (Guimarães et al. 2019, Urban et al. 2020). The substantial number of records, the consistent presence, and the distribution of the jackal in Slovakia shows that they occur in areas with presence of wolves, lynx, and bears (Lešová \& Antal 2015, Guimarães et al. 2019). Until now, there was no strong evidence reported of jackal, wolf, lynx, and bear coexisting in the same habitats, especially in mountain areas. Although it falls in the pattern of an anecdotal sympatric occurrence, we report the first strong evidence in Slovakia of a jackal in the same location as the three large carnivores, with an opportunistic camera trap record. We analyse the sympatric occurrence, describing the characteristics of the location and we review if any other occurrences of the jackal were reported within the region and in the neighbouring countries.

\section{Material ANd Methods}

\section{Study area}

The study area is located in the Kysucké Beskydy Mountains, within the East part of the Kysuce protected landscape area (Kysuce PLA), in Žilina County and part of the Western Carpathians Arc. The East part of this area borders with Poland (Żywiec Beskids) and it is $16 \mathrm{~km}$ far from the border with Czech Republic (Fig. 1). Kysuce PLA was designated a protected landscape area in 1984 and with habitats and species of European importance present in the area, it is part of the NATURA 2000 network (Kysucké Beskydy SKUEV0288).

The altitude ranges and geographical characteristics of the region influence climatic conditions. It comprehends two very humid climatic areas with a milder difference between summer and winter. One area is moderately cool, with summer temperature average in July around $14^{\circ} \mathrm{C}$ and with winter average temperatures between $-2^{\circ} \mathrm{C}$ and $-4^{\circ} \mathrm{C}$ in January. The second area is moderately warm highlands, mostly above $500 \mathrm{~m}$ a.s.1., with the summer temperature average varying between $4^{\circ} \mathrm{C}$ to $7^{\circ} \mathrm{C}$ in July 
and average winter temperatures falling below $-5^{\circ}$ C in January (Panek \& Pokluda 2006, Szalai et al. 2013). Due to the climatic and geological conditions, the area is rich in water with transitional peat bogs and peat meadows, which comprehend a variety of rare and endangered plant species (Václavova 2020). Forests stands are predominant in the region, with highly preserved natural reserves of mixed forests composed mainly of lindens, elms, and maples, as in the nature reserve of Vel'ká Rača (Václavova 2020). Besides the presence of the three large carnivores, the area is also rich in fauna with a wide variety of vertebrates and invertebrate species. The most threatened species in the region are two charismatic rare birds, the capercaillie (Tetrao urogallus) and the black stork (Ciconia nigra) (Drengubiak 2020).

\section{Camera traps}

Two camera traps (hereinafter CT1 and CT2) were set up on the $20^{\text {th }}$ of June 2019 and stayed active until the $2^{\text {nd }}$ of September 2019. We target the collection of evidence of the presence of wolves and lynx, and therefore the jackals' data collected from the camera trap is opportunistic. The camera trap's location was determined within a mountainous habitat typical for the presence of the two species and it was supported on information provided by local experts. Both camera traps were installed in an old forest road, within the village of Zborov nad Bystricou. Distancing $\sim 50$ meters from each other, CT1 was located more north than CT2, both with altitude average of $820 \mathrm{~m}$ a.s.1.. Camera traps where located 4 $\mathrm{km}$ from the highest point of the region (Vel'ká Rača 1.236 masl) and distanced $\sim 3 \mathrm{~km}$ from borders with Poland and $\sim 16 \mathrm{~km}$ from the borders with the Czech Republic. We installed two camera traps Reconyx PC900 Hyperfire Professional Covert Camera with black flash, programmed in "aggressive mode": five consecutive pictures per trigger (hereinafter GP), in fast mode, with 0 seconds between triggers and in low sensitivity motion detection. We considered each GP as one single evidence sample, to account the presence of a species as long it was just one animal involved. To decrease the possible error of counting the same individual in various GP we considered each interval of 30 minutes a single GP. Collection of the data from the camera trap occurred just once ( $8^{\text {th }}$ of August) to avoid the contamination of the spot with human scent.

To understand if this record was or not regionally isolated, we gathered all available data of the

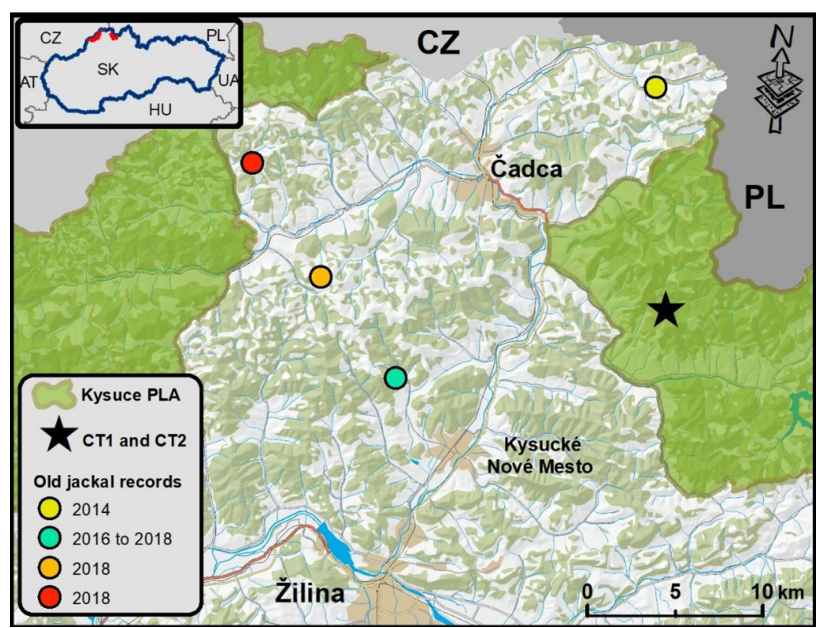

Figure 1: Map of the area with representation of the location of the camera traps (star), Kysuce PLA (light green polygons), international borders, and previous evidence records jackal by year of occurrence (coloured circles)

presence of jackals reported (observed and/or shoot) within a radius of $30 \mathrm{~km}$ from the camera traps (Fig. $1)$. The choice on the "radius" of $30 \mathrm{~km}$, was based on the half of the distance covered by a migrant female jackal $(61.2 \mathrm{~km})$, monitored with a GPS collar in Hungary (Lanszki et al. 2018).

\section{Results}

From the two camera traps, CT1 captured the jackal with the three large carnivores, while CT2 just recorded wolves, bears, and ungulates. As we centred our report on the data of the jackal, just the records of the CT1 were analysed. With CT1, we collected 85 GP in 75 camera trap days corresponding to 1858 pictures. Wild species were recorded in $50.5 \%$ of the group pictures (43 GP), $2.4 \%$ (2 GP) corresponded to anthropogenic records (human and domestic dog) and within the remaining $47.1 \%$ (40 GP) no species were identified (tab.1). The movement of the jackal was recorded in direction North-South (CT1 to CT2) on the $21^{\text {st }}$ of June at 3:19 am, less than 24 hours of the activation of the $\mathrm{CT}$, being the first carnivore species recorded on the camera trap. Jackal recognition was determined according to specific facial shape, the size and shape of the ears, and by comparison with the size of the recorded wolves and lynx. Besides the records of the jackal and the three large carnivores, we also identify the presence wild ungulates as the red deer (Cervus elaphus), the roe deer ( $\mathrm{Ca}$ preolus capreolus), and the wild boar (Sus scrofa). There was no register of the presence of any other species. From all carnivores, just the jackal showed 
Table 1: Data from camera trap by monthly records identified the jackal in one single day and three large carnivores on 12 occasions

\begin{tabular}{lcccc} 
& June & July & August & Total \\
\hline Jackal & 1 & 0 & 0 & 1 \\
Wolf & 1 & 1 & 0 & 2 \\
Bear & 1 & 2 & 2 & 5 \\
Lynx & 0 & 1 & 3 & 4 \\
Red deer & 5 & 12 & 5 & 22 \\
Roe Deer & 1 & 3 & 2 & 6 \\
Wild boar & 1 & 1 & 3 & 5 \\
Dog & 0 & 1 & 0 & 1 \\
Hunter & 0 & 0 & 1 & 1 \\
\hline \multicolumn{1}{c}{ Total } & 10 & 20 & 15 & 45
\end{tabular}

behaviour disturbances by the presence of the camera trap. The jackal reacted when approached the CT1 and sensor activated, retreating and showing signs of discomfort with the presence of the camera trap. From the data collected is not possible to ensure that the animal proceeded his way along the forest road, although, if he continued its primary direction he would be much probably recorded in CT2.

In terms of the order of the records of occurrence of the four species (Fig. 2), the jackal was the first carnivore species recorded on the camera trap, followed by a wolf, a day and a half afterwards $\left(22^{\text {nd }}\right.$ of June), a bear 5 days later ( $26^{\text {th }}$ of June) and a month later a lynx ( $27^{\text {th }}$ of July). In total, we collect one GP with the jackal, two with wolf, five with bear, and four with lynx.

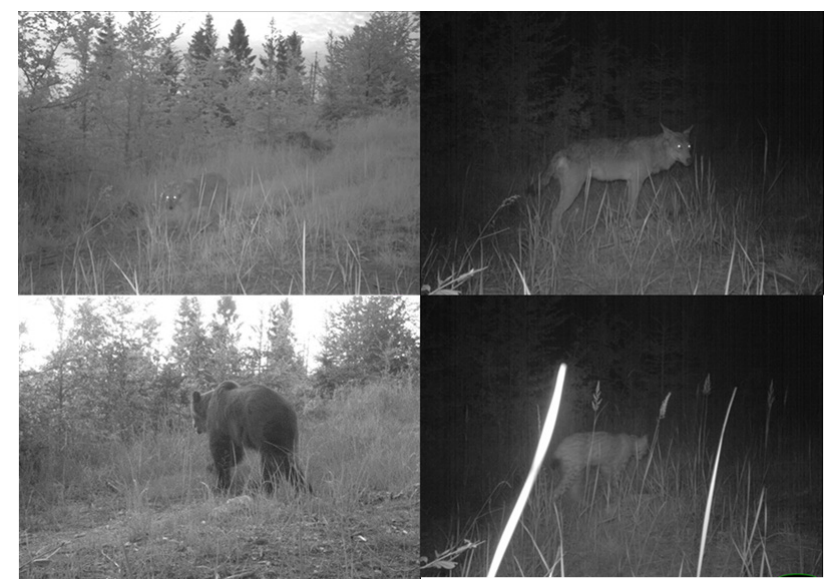

Figure 2: Pictures collected from the camera trap from the four carnivores. With temporal order of collection: jackal (top left), wolf (top right), bear (down left) and lynx (down right).
Comparing the spatial location of the camera traps with official data of records of presence of the jackal within the defined radius, we found four locations with previous data on jackal, from 2014 until 2018. From all four locations, just one presented strong evidence, with a shot individual in 2018 near Turzovka village, $\sim 25 \mathrm{~km}$ north-west from CT (red circle in Fig. 1). Within this location, one observed jackal was reported in the same year. In terms of observation records, the oldest record we found is from 2014 in Skalité village, from one single individual, $\sim 13 \mathrm{~km}$ north from the CT (yellow circle in Fig. 1). In Kysucké Nové Mesto, $16 \mathrm{~km}$ south-west from CT, from 2016 until 2018, there was two reported animals observed each year (light green circle in Fig. 1). Finally, in 2018 in Zákopčie village, $\sim 20 \mathrm{~km}$ west from CT, two observed individuals were reported (orange circle in Fig. 1). In relation to records reported in neighbouring countries, we found two records, one from Poland and one from the Czech Republic not so far away from the camera traps location. In Poland, a jackal was found dead involved in a vehicle collision in 2019, near Kraków, and distancing 110 $\mathrm{km}$ from camera traps(Kowalczyk et al. 2020). In the Czech Republic, there was an individual reported in 2014, in Kunín (Nový Jičín, northern Moravia), 70 $\mathrm{km}$ from camera traps (Hudeček \& Jakubec 2014).

\section{Discussion}

In this short communication, we report a "hard fact", C1 evidence (Hatlauf et al. 2016), of a sympatric occurrence between the jackal, wolf, lynx, and bear in Slovakia. This record is potentially important and can increase the perspective of existent knowledge of the jackal coexistence with large carnivores 
(Giannatos et al. 2005, Krofel et al. 2017). Although, due to the record characteristics, it should be valued as an anecdotal occurrence (Bates \& Byrne 2007, McKelvey et al. 2008, Kaufman \& Kaufman 2015). First, because the spatial selection for the location of the camera traps targeted other species rather than jackal (wolf and lynx) and second because besides the length period in which camera traps were active, it was recorded just in a single event.

It is clear that the location of the record in mountainous and pure forest habitat presents an atypical record for a jackal habitat, as they normally prefer lowlands and agricultural landscapes (Giannatos 2004, Śálek et al. 2014, Spassov \& Pankov 2019, Torreta et al. 2020). At the same time the altitude above the $800 \mathrm{~m}$ a.s.1, indicates an occasional occurrence of a jackal, as they are much more common in areas with altitudes under the $600 \mathrm{~m}$ a.s.l. (Giannatos 2004, 2005, Śálek et al. 2014).

One interesting trait of this record is the step back reaction that the jackal presented when in presence with the camera trap. This reaction may be linked to the species' shyness (REF), but also to some external factors that also need to be accounted for in its analysis. First, the reaction could result from the sound and lights of the camera trap. Second, the animal could still notice and react to the presence of human smell in the area as the camera trap was installed less than 24 hours before. The fact the jackal was not recorded for all the study length, could be due to the presence of a wolf in the same location. Confirmed one day after the record of the jackal, presence of wolves could inhibit the return of the jackal to the camera trap area, as this large carnivore can induce a change in behaviour of the mesocarnivore (Krofel et al. 2017, Haswell et al. 2018). The late time of the evidence $(3: 19 \mathrm{am})$ can suggest that the individual travels in a less human disturbing hour to avoid the contact. Nevertheless, this sort of single event occurrence is inconclusive in defining if the individual reported was a vagrant, dispersal, or resident individual (Trouwborst et al. 2015).

The record of this sympatric event contributes to the growing body of knowledge about the dispersion of jackals in Europe. It is reasonable to expect for a continuous dispersion and increase of density of the jackal in Slovakia following last decades records (Guimarães et al. 2019, Urban 2020). Having in count the presence of the big three large carnivores in Slovakia is presently stable, it is certain that more records of sympatric occurrences between the four species are highly probable to become more common in the future.

\section{ACKnowledgements}

We would specially thank to Martin Hromada (UNIPO) for comments and suggestions that help us to improve our manuscript. Also thanks to Peter Drengubiak (SOPSR) and Michal Kardoš (Lesy SR) and Jana Durová for their support in the fieldwork and literary research. The study was supported partially by the European Regional Development Fund, based on the support of the Cross-border Cooperation Program Slovak Republic - Czech Republic 2014-2020 and the implementation of the project INTERREG V-A SK-CZ 304021D016 with the title: "Coordination of protection, monitoring and management of the West Carpathian population of the wolf and the lynx on the Czech-Slovak border".

\section{REFERENCES}

Ambarli, H., Erturk, A. \& Soyumert, A. 2016: Current status, distribution, and conservation of brown bear (Ursidae) and wild canids (gray wolf, golden jackal, and red fox; Canidae) in Turkey. Turkish J. Zool. 40: 944-956.

Arnold, J., Humer, A., Heltai, M., Murariu, D., Spassov, N. \& Hacklaender, K. 2012: Current status and distribution of golden jackals Canis aureus in Europe. Mamm. Rev. 42: 1-11.

Bates, L.A. \& Byrne, R.W. 2007: Creative or created: using anecdotes to investigate animal cognition. Methods, 42(1): 12-21.

Drengubiak, P. (2020): Chránená krajinná oblast Kysuce: Fauna [Kysuce Protected Landscape Area: Flóra]. Retrieved from http://chkokysuce.sopsr.sk/priroda/ fauna/. (In Slovak)

Demeter, A. \& Spassov, N. 1993: Canis aureus Linnaeus, 1758. In: (J. Niethammer and F. Krapp, eds.) Handbuch der Säugetiere Europas. Wiesbaden, Aula-Verlag: 107-138. (in German)

Giannatos, G., Marinos, Y., Maragou, P. \& Catsadorakis, G. 2005: The status of the golden jackal (Canis aureus L.) in Greece. Belg. J. Zool. 135: 145-149.

Giannatos, G. 2004: Conservation action plan for the golden jackal Canis aureus L. in Greece. WWF Greece: 47.

Ginsberg, J.R. \& Macdonald, D.W. 1990: Foxes, wolves, jackals, and dogs: an action plan for the conservation of canids. IUCN, Gland, Switzerland.

Guimarães, N., Bučko, J., Kušík, P. \& Urban, P. 2017: What do we know about the golden jackal (Canis au- 
reus, L. 1758) in Slovakia? In: (J. Bryja, M. Horsák, V. Horsaková et al., eds.) Abstract proceedings from the conference. Zoologické dny, 9.-10. February, Brno, Czech Republic.

Guimarães, N., Bučko, J. \& Urban, P. 2019: The rise of a carnivore, the evolution of the presence of the golden jackal in Slovakia. Folia Zool., 68(2): 66-71.

Haswell, P.M., Jones, K.A., Kusak, J. \& Hayward, M.W. 2018: Fear, foraging and olfaction: how mesopredators avoid costly interactions with apex predators. Oecologia, 187(3): 573-583.

Hatlauf, J., Heltai, M., Szabó, L. \& Hackländer, K. 2017: Golden jackal (Canis aureus) occurrence in Austria: from first records to recent findings. 33rd International Union of Game Biologists Congress, IUGB, Montpellier.

Hatlauf, J., Banea, O.C. \& Lapini, L. 2016: Assessment of golden jackal species (Canis aureus, L. 1758) records in natural areas out of their known historic range. Technical Report, GOJAGE Criteria and Guidelines. Gojage E-Buletin: 7.

Holt, R.D. \& Polis, G.A. 1997: A theoretical framework for intraguild predation. The American Naturalist, 149(4), pp.745-764.

Hudeček, J.J. \& Jakubec, M. 2014: Šakal obecný (Canis aureus) pronikl do Moravské brány [The jackal ( $\mathrm{Ca}$ nis aureus) penetrated the Moravian Gate]. Poodř́ 2014/2: 11-13 (in Czech)

Jhala, Y.V. \& Moehlmann, P.D. 2004: Golden jackal $\mathrm{Ca}$ nis aureus. In: (Sillero-Zubiri, C., M. Hoffmann \& D. Macdonald eds.) Canids: Foxes, Wolves, Jackals and Dogs Status Survey and Conservation Action Plan. IUCN/SSC Canid Specialist Group Gland, Switzerland: 156-161.

Jhala, Y.V. \& Moehlmann, P.D. 2008: Canis aureus. The IUCN Red List of Threatened Species 2008: e. T3744A10054631. Accessed 19 May 2016.

Jirků, M., Dostál, D., Robovský, J. \& Šálek, M. 2018: Reproduction of the golden jackal (Canis aureus) outside current resident breeding populations in Europe: evidence from the Czech Republic. Mammalia, 82(6): 592-595.

Kaufman, A.B. \& Kaufman, J.C. 2015: Animal creativity and innovation. Academic Press.

Kowalczyk, R., Wudarczyk, M., Wójcik, J.M. \& Okarma, H. 2020: Northernmost record of reproduction of the expanding golden jackal population. Mamm. Biol., 100(1): 107-111.

Krofel, M., Giannatos, G., Ćirović, D., Stoyanov, S. \& Newsome, T.M. 2017: Golden jackal expansion in
Europe: a case of mesopredator release triggered by continent-wide wolf persecution?. Hystrix, 28(1): 9-15.

Kryštufek, B., Murariu, D. \& Kurtonur, C. 1997: Present distribution of the Golden Jackal Canis aureus in the Balkans and adjacent regions. Mammal Rev., 27(2): 109-114.

Lanszki, J., Schally, G., Heltai, M. \& Ranc, N. 2018: Golden jackal expansion in Europe: First telemetry evidence of a natal dispersal. Mamm. Biol., 88(1): 81-84.

Lanszki, J., Kurys, A., Heltai, M., Csányi, S. and Ács, K., 2015, August. Diet composition of the golden jackal in an area of intensive big game management. In Annales Zoologici Fennici (Vol. 52, No. 4, pp. 243-255). Finnish Zoological and Botanical Publishing Board.

Lanszki, J., Kurys, A., Szabó, L., Nagyapáti, N., Porter, L.B. \& Heltai, M. 2016: Diet composition of the golden jackal and the sympatric red fox in an agricultural area (Hungary). Folia Zoologica, 65(4): 310-322.

Lanszki, J. \& Heltai, M. 2010: Food preferences of golden jackals and sympatric red foxes in European temperate climate agricultural area (Hungary). Mammalia, 74 (3): 267-273.

Lešová, A. \& Antal, V. 2015: Ochrana a manažment vel'kých šeliem na Slovensku [Protection and management of large carnivores in Slovakia]. Banská Bystrica: Štátna ochrana prírody Slovenskej republiky. (in Slovak)

Macdonald, D.W., 1979: The flexible social system of the golden jackal, Canis aureus. Behavioral Ecology and Sociobiology, 5 (1): 17-38.

McKelvey, K.S., Aubry K.B. \& Schwartz M.K. 2008: Using anecdotal occurrence data for rare or elusive species: the illusion of reality and a call for evidentiary standards. BioScience, 58(6): 549-555.

Newsome, T., Greenville, A., Ćirović, D., Dickman, C., Johnson, C., Krofel, M., Letnic, M., Ripple, W., Ritchie, E., Stoyanov, S. \& Wirsing, A. 2017: Top predators constrain mesopredator distributions. Nature Communications 8: 1-7.

Pánek, T. \& Pokluda, F. 2006: S batohom po Slovensku. [With a backpack around Slovakia]. Dajama, Bratislava. (in Slovak)

Pasanen-Mortensen, M., Pyykönen, M. \& Elmhagen, B. 2013: Where lynx prevail, foxes will fail-limitation of a mesopredator in E urasia. Global Ecology and Biogeography, 22(7): 868-877.

Penezić A. and Ćirović D. 2015: Seasonal variation in diet of the golden jackal (Canis aureus) in Serbia. Mammal Research, 60(4), pp.309-317. 
Rutkowski, R., Krofel, M., Giannatos, G., Ćirović, D., Männil, P., Volokh, A.M., Lanszki, J., Heltai, M., Szabó, L., Banea, O.C. \& Yavruyan, E.. 2015: A European concern? Genetic structure and expansion of golden jackals (Canis aureus) in Europe and the Caucasus. Plos One, 10(11).

Ranc, N., Krofel, M. \& Ćirović, D. 2018: Canis aureus (errata version published in 2019). The IUCN Red List of Threatened Species 2018: e. T118264161A144166860. Downloaded on 12 June 2020.

Ritchie, E.G. \& Johnson, C.N. 2009: Predator interactions, mesopredator release and biodiversity conservation. Ecol. Lett. 12: 982-998.

Š́alek, M., Červinka, J., Banea, O.C., Krofel, M., Ćirović, D., Selanec, I., Penezić, A., Grill, S. \& Riegert, J. 2014: Population densities and habitat use of the golden jackal (Canis aureus) in farmlands across the Balkan Peninsula. Eur. J. Wildlife Res., 60(2): 193-200.

Štofik, J., Merganič, J., Merganičová, K. \& Saniga, M. 2013: Seasonal changes in food composition of the brown bear (Ursus arctos) from the edge of its occurrence-Eastern Carpathians (Slovakia). Folia Zoologica, 62(3): 222-231.

Sillero-Zubiri, C., Hoffmann, M. \& Macdonald, D.W. 2004: Canids: foxes, wolves, jackals and dogs: status survey and conservation action plan, 2nd ed. IUCN Canid Specialist Group, Gland, Switzerland and Cambridge, U.K.
Slamka, M., Kaštier, P. \& Schwarz, M. 2017: The golden jackal in Slovakia. Canid Biol. Conserv. 20(9): 38-41.

Spassov, N. \& Acosta-Pankov, I. 2019: Dispersal history of the golden jackal (Canis aureus moreoticus Geoffroy, 1835) in Europe and possible causes of its recent population explosion. Biodiversity Data Journal 7.

Szalai, S., Auer, I., Hiebl, J., Milkovich, J., Radim, T. Stepanek, P., Zahradnicek, P., Bihari, Z., Lakatos M., Szentimrey, T., Limanowka, D., Kilar, P., Cheval, S., Deak, Gy., Mihic, D., Antolovic, I., Mihajlovic, V., Nejedlik, P., Stastny, P., Mikulova, K., Nabyvanets, I., Skyryk, O., Krakovskaya, S., Vogt, J., Antofie, T. \& Spinoni, J. 2013: Climate of the Greater Carpathian Region. Final Technical Report. www.carpatclim-eu. org. CARPATCLIM Database (C) European Commission - JRC.

Trouwborst, A., Krofel, M. \& Linnell, J.D. 2015: Legal implications of range expansions in a terrestrial carnivore: the case of the golden jackal (Canis aureus) in Europe. Biodiver. Conserv., 24(10): 2593-2610.

Urban, P., Guimarães, N. and Bučko, J., 2020. Golden jackal, a natural disperser or an invasive alien species in Slovakia? A summary within European context. FOLIA OECOLOGICA, 47(2).

Václavova, Z. (2020) Chránená krajinná oblast Kysuce: Flóra [Kysuce Protected Landscape Area: Flóra]. Retrieved from http://chkokysuce.sopsr.sk/priroda/flora/. (In Slovak) 